PLANNING MALAYSIA

Geospatial Anelysis in Urbon Planning

Volume II (2013), Page 39 - 56

\title{
GREEN SPACE AUDITS ON ITS ACCESSIBILITY IN PASIR GUDANG
}

\author{
Wan Yusryzal Wan Ibrahim', Ahmad Long ${ }^{2}$ \& Ariva Sugandi Permana ${ }^{2}$ \\ ${ }_{1.283}$ Centre for Jnovative Planning and Development (CiPD) \\ Faculty of Built Environment \\ UNIVERSITI TEKNOLOGI MALAYSIA
}

\begin{abstract}
Green space is an essential element in a city that serves outdoor recreational place for the community. It helps generating the economic and social values and promoting a healthy lifestyle for local community. The aim of the study is to audit the green spaces in Pasir Gudang Municipality and promote the strategies to improve the use of green space in the study area towards better quality of life of the citizens. The study classifies the existing green spaces in Pasir Gudang in terms of size, function, use, quality, area, accessibility and facilities provided in the green space areas. Two key points have been identified as a basic reference before any development of green spaces take place in Pasir Gudang. The study reveals that present green space areas in Pasir Gudang Municipality are able to serve most communities in the municipality. However, still about $35 \%$ of the municipality area is not presently served by the existing green spaces. Thus quantity, quality and accessibility of the green space areas need improvenxent. This study also shows the potential network of the access that will be able to improve the approachability of all existing green space areas by the citizens to contribute to their quality of life.
\end{abstract}

Keywords: green space auditing, accessibility, geographic information system, quality of life.

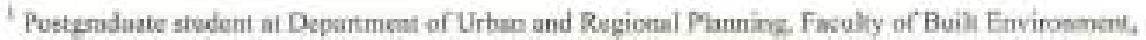
Universiti Tekoologi Malzysiz. E-mail: kyusryzsLRe utmany (Corresponding authoe)
} 


\section{INTRODUCTION}

Green space is defined as any piece of land covered with vegetation. It usually refers to parks, golf courses, sports fields and other open land within the builtup area, whether publicly accessible or not. In many countries, open spaces are nowadays regarded as integral part of land use planning decisions. However, approaches to open space planning vary, and there is no general agreement on the desirable planning criteria as to how much open space is needed, where open spaces should be located or how they should be used (Maruani and Cohen 2007). In Malaysia, green space considered as open space. Aceording to Department of Town and Regional Planning under the Town and Regional Planning Act (Amendment) 1995 (A933), open space is defined as any land either gated or not, which had been specifically and fully reserved or a part of it, to be used as garden, public park, football field, public recreation area or as public place. Also, the hierarchy and characteristic (size and catchment area) of open space can be elassified as national park (no limitation on size, all countries), regional park (100 hectares, all regions), town park/urban Park (40 hectares, 50,000 people and above), Iocal park ( 8 hectares and above but not exceed 40 hectares, 12,000 to 50,000 people), neighbourhood park ( 2 hectares and above but not exceed 8 hectares, 3,000 to 12,000 people), play field ( 0.6 hectares and above but not exceed 2 hectares, 1,000 to 12,000 people) and play lot $(0,2$ hectare and below, 300 to 1,000 people).

The distribution and catchment area for different type of green spaces are shown in Figure 1. It shows that green space concerns with any development. However, with the rapid land use change, it is necessary to revisit the functionality of existing green space. Besides that, green space it also provides a 'Green Lung' for a city, serve as focal points that can break monotony of concrete jungle, promote bealthy society by providing spaces for recreational, social and leisure activities and also counterbalance the harsh reality of a hectic urban life. A well-distributed green space can influence the quality of life of people (Federal Department of Town and Country Planning 2005). 

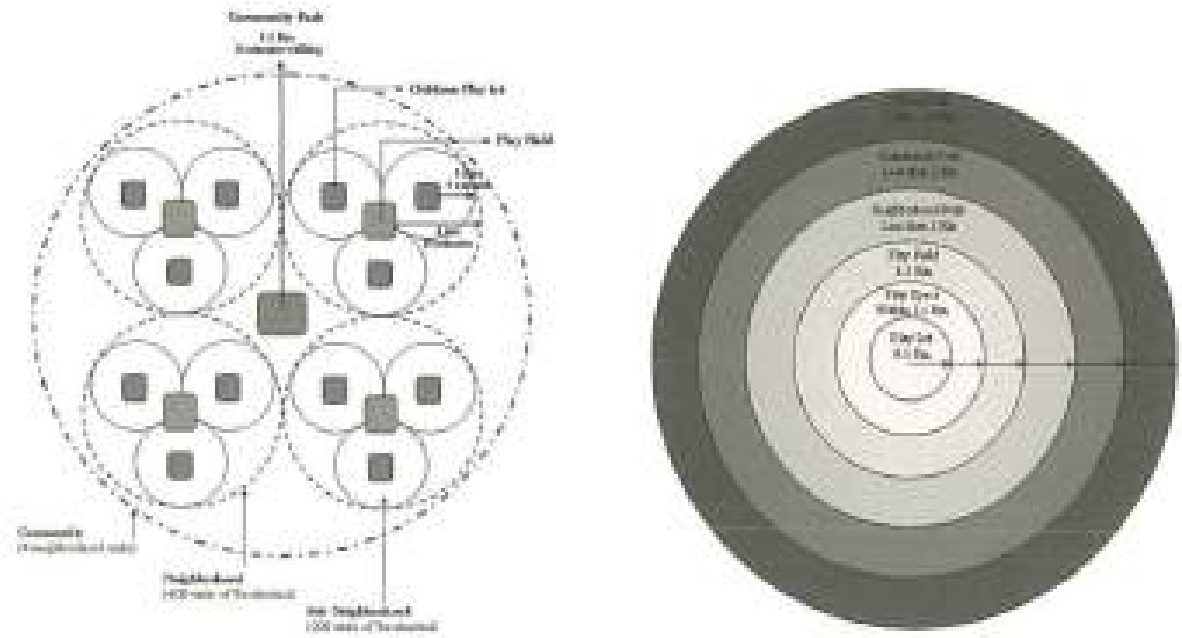

Figure 1: Distribution of (a) catchment area (b) green spaces according to Malaysia's Planning Standard

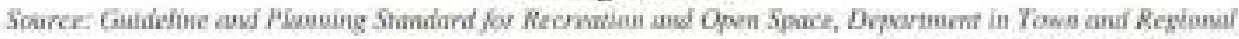
phanning. Peniandar Malaysia.

Meanwhile the amount of provision, the distribution of green space and the ease of access to such spaces are key contributors to social and ecological functions in urban environments (Barbosa et al. 2007). Parks and green spaces have a major contribution to the liveability of city centre by creating informal recreation which serve as an outdoor recreational place and provide leisure activity for social groups.

The presence of greenery area can also help to protect natural environment, improve air quality and ensure the urban dwellers have access to recreational site. The bealth policy in the United Kingdom, for example, has been increasingly advocating the use of outdoor green space to improve health and there has been a growing emphasis on the health improvements connected with use of the natural enviroument (Kessel and Green 2009). Other than that, green spaces serve as protective elements to the unique character of rural communities which might otherwise be absorbed by expanding suburbs area. It also functioning as a place for local community to leam and experience outdoor environment. Therefore, there is a strong reason that green spaces contribute towards promoting social inclusion on health and well-being of the conmunity and act as important local education resources. 
Green space becomes more and more important element of a city for its psychological role in community well-being. People who live in urban areas with more green space tend to report greater well-being than city dwellers who do not have parks, gardens, or other green space nearby (White et al. 2013). They also assert that living in an urban area with relatively high levels of green space compared to one with relatively low levels of green space was associated with a positive impact on well-being equivalent to roughly a third of the impact of being married vs, unmarried and a tenth of the impact of being employed vs. unemployed.The above study suggests that while urbanization is a potential threat to mental health and well-being, living closer to urban green spaces such as parks, is associated with lower mental distress. This shows the importance role of green space in improving quality of life of the citizens.

Green spaces might act as the 'glue' which binds the city together. They are part of a larger cohesive network of individual spaces which include the transport arterials, streets, lanes, street intersections, parks and squares. The availability of green space in the living environment may be an important environmental factor that moderates the relationship between stressful life events and health (Berg et al. 2010). Meanwhile, urban green spaces are universally valued as amenity-recreation venues, wildife refuges and essential liveable-city ingredients (Jim and Chen 2003). The various benefits of green space bad been identified through various studies established by many researchers. These benefits are generally much dependent on the way that the green spaces are planned, designed and managed by authority where it belongs. It is important to ensure that all these resources have strong impaet on quality, accessibility and adequate quantity to serve local community.

Geographic Information Systems is one of the best tools to implement environmental analysis. The most importance of GIS is about its capability to handle spatial and attribute data (Ahris 1994). The integration of the GIS and Remote Sensing will contribute to better results. It enhances the research results through the improvement of the interpretation of the earth surface. The application of planning standard for green spaces distribution and catchment areas with GIS is beneficial to understand the current issues. There are many advantages in GIS that can be used in analysing the real world system. GIS can be applied to analyse line and point features based on topology nules. It is a useful tool in analysing water distribution, stream flows, and traffic flows, whereby centres, links, nodes, and impedance are key elements in that analysis (Kyushik and Seunghyun 2007). It also provides network-based spatial analysis, such as routing, fleet routing, travel directions, closest facility, service area, and location-allocation. 
Green space audit is carried out to identify how extent the green space areas exists, including its distribution and accessibility. Due to the rapid development and land use changes, it is then necessary to look th the functionality of green spaces. The goal of this study is to identify and evaluate the green space areas in Pasir Gudang Municipality. There are two objectives in this study. First: to audit various types of green spaces in the study area, and second: to look at the function of green space areas in terms of coverage and accessibility. This audit is carried out to see whether or not the selected area has sufficient coverage and quality of the green space areas for local community, as well as to establish an accurate view of the service level of the green space areas and proposed fundamental strategies to improve the connectivity and accessibility of the green space areas. Green space audit in this study covers several assessments particularly with respect to its quantity (area) and accessibility.

\section{STUDY AREA}

The study area is area under the administrative unit of Pasir Gudang Local Authority or Majlis Perbandaran Pasir Gudang, Johor (MPPG) as exhibited in Figure 2. The area was selected because of its potential luture development under Iskandar Malaysia Development Region. Pasir Gudang becomes one of the key components of development of Iskandar Mulaysia that is put under the Eastern Gate Development and Special Economic Corridor (SEC), Eastern Gate is the industrial and manufacturing hub in the southern region of Peninsular Malaysia. This hub encompasses 31,132 ha in Pasir Gudang Municipality.

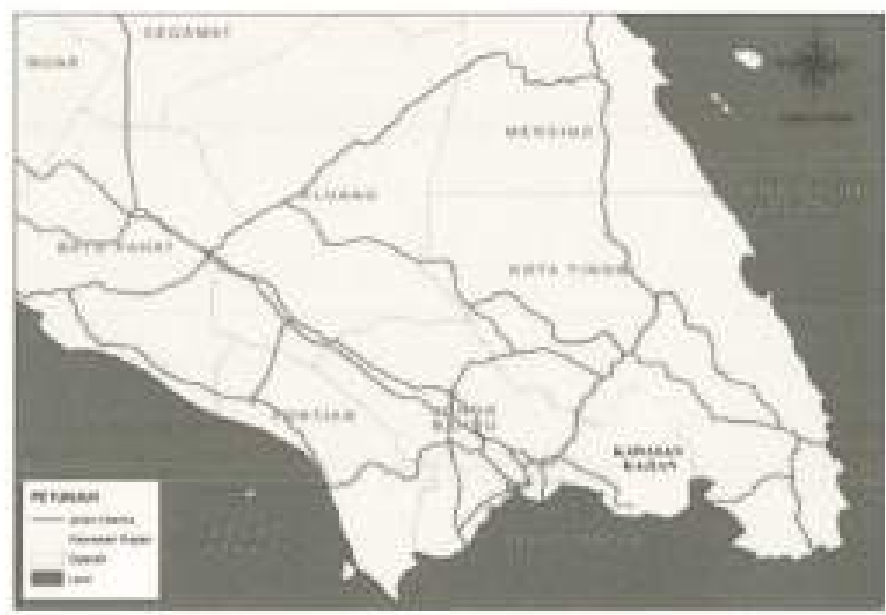

Figure 2: Location of the Study Area 
The complexity of the development issues and the increase of population are seemingly the fundamental issues that contribute to the environmental sustainable matters in the Pasir Gudang Municipality. This study attempts to understand the greenery as one of the key components to improve quality of life towards the sustainable livelihood in Pasir Gudang Municipality. It is believed that the presence of sufficient green space areas with adequate accessibility in the city contributes to the happiness of the cifizens towards sustainable quality of life.

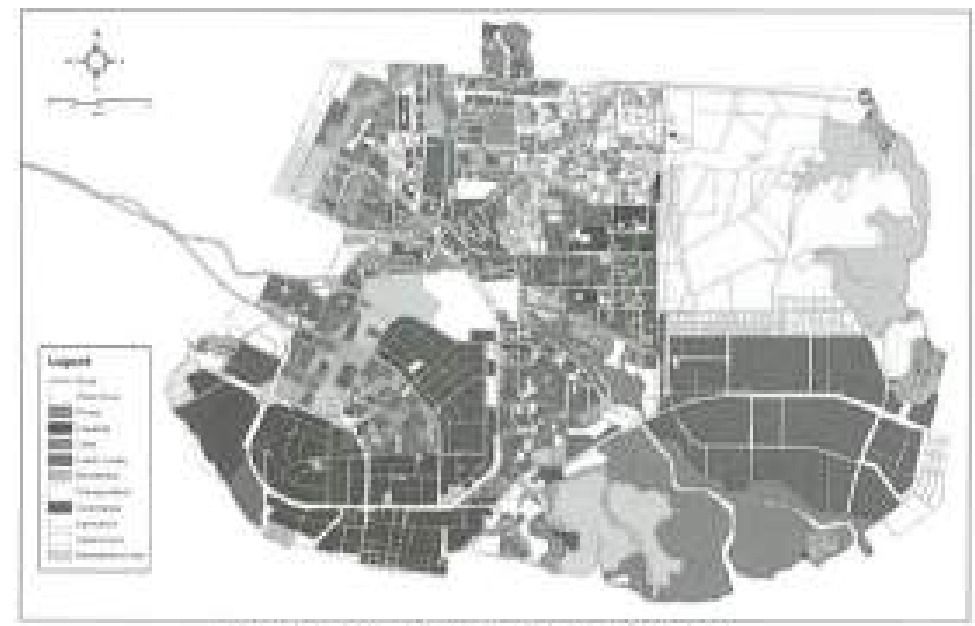

Figure 3: Land Use of Pasir Gudang

Table It Area and Percentage of Land Use in the Study Area

\begin{tabular}{|l|r|r|}
\hline \multicolumn{1}{|c|}{ Land use } & Acreage (Hectare) & Percentage (\%) \\
\hline Housing & 578,23 & 4.39 \\
\hline Commercial & 38.09 & 0.29 \\
\hline Industry & $1,296.41$ & 9.84 \\
\hline Institution & 192.17 & 1.46 \\
\hline Open Space and Recreation Area & 222.86 & 1.69 \\
\hline Vacant Land & $4,113.70$ & 31.23 \\
\hline Forest & 772.55 & 5.86 \\
\hline Agriculture Land & $3,697.31$ & 28.07 \\
\hline Water bodies & 930.75 & 7.07 \\
\hline Utility & 322.20 & 2.45 \\
\hline Street and Trumsportation & 1.009 .73 & 7.66 \\
\hline Total & $13,174.00$ & 100.00 \\
\hline
\end{tabular}


The main components of the land use of Pasir Gudang are agricultural land, open space, industrial and residential areas as shown in Figure 3 and quantitatively reflected in Table 1. Major economic activities in the Pasir Gudang area are electrical and electronic, chemical, oleo-chemical, chemical biofuels, plastic and food products, engineering-based industries, ports and logistics, warehousing, as well as research and development. The study area is mainly characterized by mix land use development, as shown in Figure 4. Most of the green spaces exist in this zone is at scattered manner.

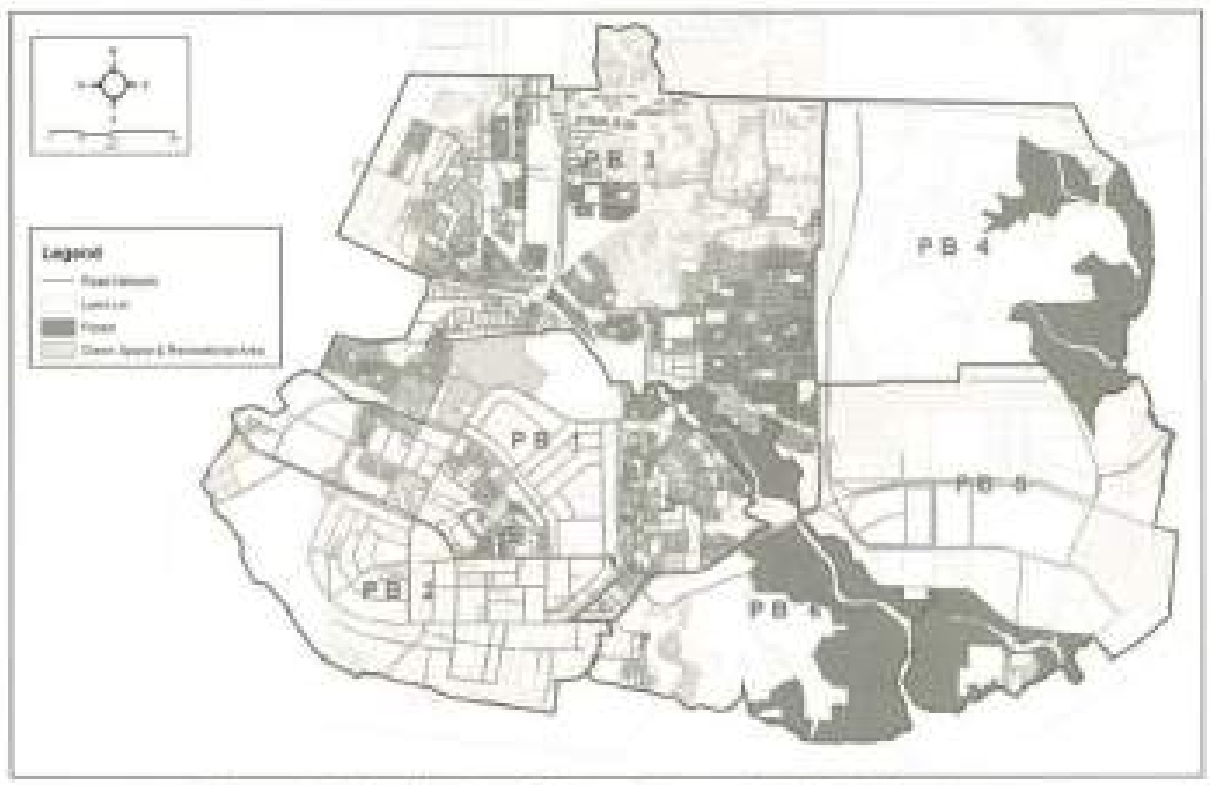

Figure 4: Distribution of Green Spuces in the Study Area

The accessibility of the existing green space areas in Pasir Gudang seems adequate, since they have no barriers to free entry such as round-theclock access, no admission charge applied, available road access from community centres to the green space areas, and sufficient parking lots for the visitors. However, room for improvement with respect to accessibility is still there. The improvement can be, among other, done through enhancement of the accessibility of the green space areas and connectivity between the users i.e. community centres and the green space areas. This study attempts to understand this issue by means of employing geographic information system as a tool for analysis and appropriate methods of study. 


\section{METHODS OF STUDY}

The study applies the integration of several techniques in data collection and analysis. A database was developed to accommodate the spatial data input. The Ikonos Satellite Imagery and vector data obtained from the Local Authority are the main component in this study, since the analysis was based largely on this source. Updating data and ground verifieation on land use and land cover have been made to ensure that the existing data and information are up-to-date. The ground verification of land use data and land cover was done by walkingthrough the existing green space areas and other relevant land use categories.

Data collection and analysis are two most essential stages towards best results with the support of data accuracy and suitable technique of analysis. Table 2 shows the sources, types and components of data collected and used in the study. For the accuracy of the data verification, the study area was visited several times and the measurement of the data was made with the support of Global Positioning Systems instrument. The additional data, which is necessary to support the study, were also collected and verified by using same instrument and technique.

Study uses satellite imageries. The purpose of using satellite imageries is to identify the existing green space areas and its land cover towards the acceptable level accuracy. The satellite imagery that shows "present" land use of Pasir Gudang aren is shown in Figure 5. However, due to the delay time of the image, the image might not reflect the current condition of the green spaces in the study area. That is why the ground verification was undertaken. The satelitite image is also very useful to identify both natural and artificial green space areas and get information on it in terms of geographical location, area and shape. The images are classified according to type of land use or land cover and also by greenery and built-up areus. There are two methods to classify the images, which are Supervised Classification and Unsupervised Classification. The study employs Supervised Classification method, as Richard and Jia (1993) asserted that the supervised classification is the essential tool used for extracting quantitative information from remotely sensed image data. By using this method, the analysis can be done in smoother manner since sufficient known pixels to generate representative parameters for each class of interest.

The classification process of land use and land cover was done by using image processing software. The first result of the classification has been used as a reference for the second classification in detemining the green space areas in Pasir Gudang Municipality. 
Table 2: Componeats and Sources of Data Csllection

\begin{tabular}{|c|c|c|c|}
\hline Component & Data & Shape & Source \\
\hline \multirow[t]{4}{*}{ Administration } & State Boundary & Polygan & MPPG \\
\hline & District Boundary & Polygon & MPPG \\
\hline & Mukim Boundary & Polygon & MPPG \\
\hline & Cadastral Lot & Polygan & MPPG/JPBD \\
\hline \multirow[t]{2}{*}{ Land Use } & Existing Land Use & Polygon & $\begin{array}{l}\text { MPPG/JPBD/Field } \\
\text { Work }\end{array}$ \\
\hline & Future Lanxt Use & Polygon & MPPGIJPBD \\
\hline \multirow[t]{2}{*}{ Water Body } & River & Polygon & $\begin{array}{l}\text { MPPGJJPBD/Ficld } \\
\text { Work }\end{array}$ \\
\hline & Lake & Line & $\begin{array}{l}\text { MPPG/JPBD/Ficld } \\
\text { Work }\end{array}$ \\
\hline Building & Existing Building & Image & MPPG/IPBD \\
\hline Transportation & Road Network & Line & $\begin{array}{l}\text { MPPG/JPBD/Field } \\
\text { Work }\end{array}$ \\
\hline $\begin{array}{l}\text { Pedestrian } \\
\text { Network }\end{array}$ & Pedestrian Network & Line & Field Work (CiPS) \\
\hline \multirow{2}{*}{$\begin{array}{l}\text { Recreational } \\
\text { Area }\end{array}$} & Recreational Area & Point & Ficld Work (GPS) \\
\hline & Recreational Area & Polygon & Sateflite fmage \\
\hline \multirow[t]{2}{*}{ Green Space } & Green Space & Point & Field Work (GPS) \\
\hline & Green Space & Polygon & Satellite Image \\
\hline
\end{tabular}

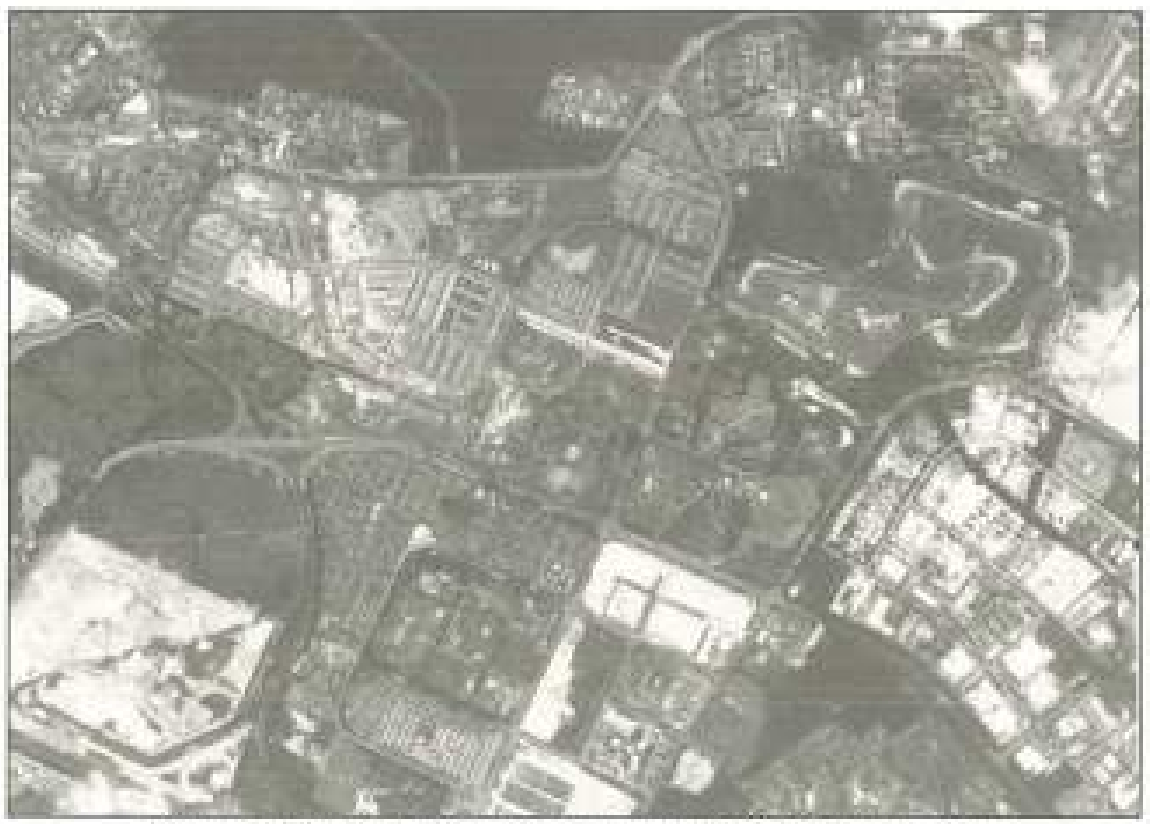

Figure 3: The Ikothos Satellite Imagery of Pasir Gudang Area 
Evaluation on the accessibility level and the coverage of service area of green space in Pasir Gudang was done by using GIS software. The analysis is based on the distribution of green spaces, roads and pedestrian networks. The connectivity and coverage of the green spaces was evaluated by following the Guidelines provided by Jabatan Perancangan Bandar dan Desa. The evaluation was done with the support of GiS functions. The service area of the green spaces was considered basing on its typology and function of its category. To identify the best network i.e. connectivity of the green space areas with the community eentres as well as eonnectivity among green space areas, a network analysis has also been done with the support of same GIS function. The analysis results reveal that connectivity of the green space areas and community eentres, as well as connectivity among the existing green space areas need improvement. Looking at this connectivity status, recommendations on the integration and connectivity of all green space areas and accessibility by the community centres in Pasir Gudang are proposed.

\section{RESULTS AND DISCUSSION}

This study largely focuses on the distribution and relation of green space typology on the accessibility and connectivity of green spaces network.

\section{Green Spaces Typology and Accessibility}

Study area has a wide range of open space with respect to size, function and use. It is also certain that some communities have been provided with easily accessible green space better than others in terms of quality, quantity and facilities of the green space areas. This issue should not appear when equal quality of life would be promoted for the whole citizens in the study area.

Satellite imageries and ground verification reveal that six planning blocks in the study area have significant provision of green space areas with respect to quality, size and facilities. The Planning Block I and 3 contain the most numbers of green space areas compared to other blocks, particularly in the eastem part of Pasir Gudang. The eastern part was actually planned to be the main industrial area of Johor Bahru, and thus contains less green spaces. Also, the residential areas in Pasir Gudang are concentrated in the western part of the Municipality. It is realistic then to hive more green spaces in the western part.

The audit process identifies 1,531.62 hectares of green space in the study area. This is quite significant figure in comparison to other areas in Johor Bathru. The auditing process was then done throughout this area. The total 
amount of green space areas in Pasir Gudang Municipality were then identified and quantified.

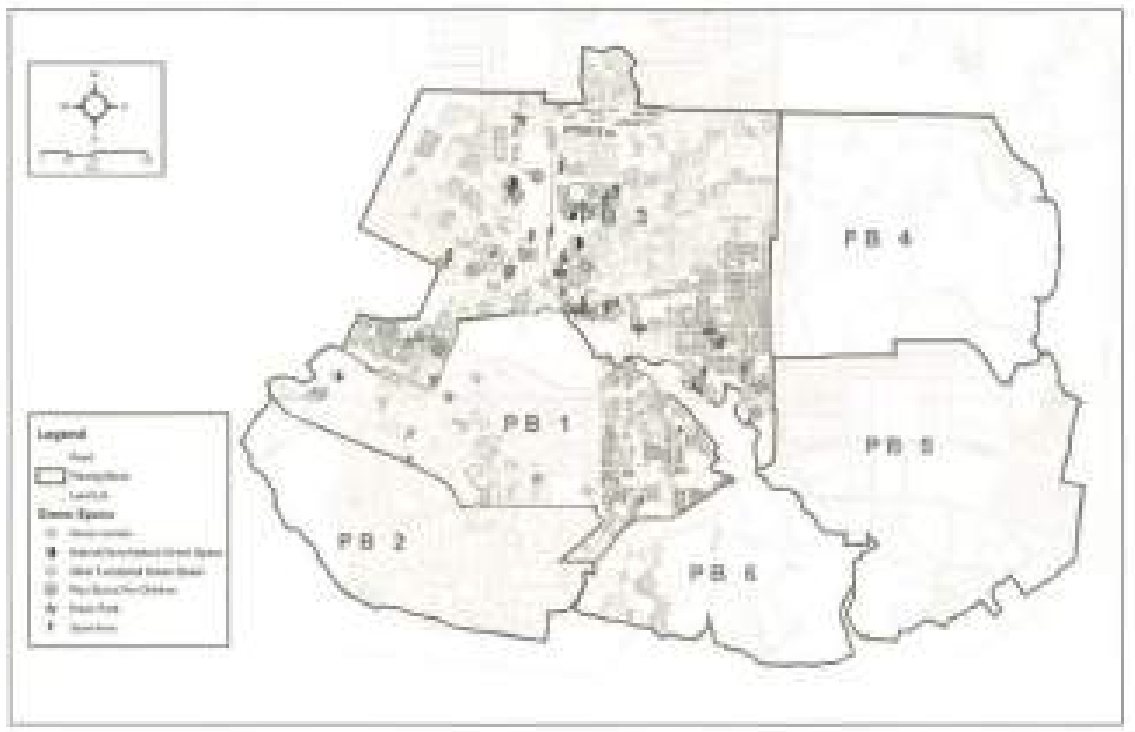

Figure 6: The Distribution of Green Space by lts Typology

Figure 6 shows all sites plotted and presented with respect to its green space typology. This figure reveals that the concentration of green space areas is in Planning Block 1 and 3. The primary function of these two blocks was residential areas. In the remaining planning blocks, the number of green space areas is not significant amid the growing increase of residential development in these parts particularly Planning Blocks 4,5 and 6 . The primary function of these three blocks was industrial areas.

Table 3: The Area and Percentage of Groen Space according to Its Typology

\begin{tabular}{|l|c|c|}
\hline \multicolumn{1}{|c|}{ Typolong } & Area (ha) & $\begin{array}{c}\text { Pereentage of Total } \\
\text { (Area) }\end{array}$ \\
\hline Public Park & 68.15 & 4.45 \\
\hline Private Ground & 688.31 & 44.94 \\
\hline Amenity Garden & - & - \\
\hline Play space & 18.38 & 1.20 \\
\hline Sports Area & 199.72 & 13.04 \\
\hline Green Corridors & 34.22 & 2.23 \\
\hline NaturalSemi natural Green Space & 522.99 & 34.15 \\
\hline
\end{tabular}




\begin{tabular}{|l|c|c|}
\hline Other functional Green Space & - & - \\
\hline Total & $1,531.62$ & 100.00 \\
\hline
\end{tabular}

Some land use conflicts would perheps arise in future when residential and industrial developments will be equipotentially promoted. Thus, authorities should be cautious on this latent issue. A number of green space areas with similat quality with other planning blocks i.e. Planning Blocks. I and 3 seems necessary to develop, with at argument that still industrial development would need sufficient greenery. The green space typology is shown in Table 3.

Table 3 shows the area of various typologies of green space areas and percentage in Pasir Gudang. It shows that private ground, which is currently greenery area, is predominant. This type of greenery is very vulnerable to land conversion since it is mostiy owned by private companies or individuals. When the land owners conver them to be built-environment, the greenery is then easily gone. A clear and suitable development control that promotes socioeconomic development while conserving environment should be appropriately implemented in this area.

Table 4: Giren Space Coverage in the Study Arca

\begin{tabular}{|l|r|r|r|}
\hline \multirow{2}{*}{ Coverage } & \multicolumn{2}{|c|}{ Area } & \multirow{2}{*}{ Percentage } \\
\cline { 2 - 3 } & \multicolumn{1}{|c|}{ In Acre } & \multicolumn{1}{|c|}{ In Hectare } & \\
\hline Inside covernge & $21,439.63$ & $8,672.67$ & 64.79 \\
\hline Outside coverage & $7,544.65$ & $3,053.21$ & 35.21 \\
\hline
\end{tabular}

Table 4 shows the total amount of green space within the whole study area. It stiows that the total area of green spaces is $1,531.62$ hectares or equivalent to $11.66 \%$ from total area of Pasir Gudang. The most common green space typology identified in the study area is private ground, which is accounting for $44.94 \%$ of the total area of Pasir Gudang. Natural and artificial green spaces occupy $\$ 22.99$ hectares in the study area. This is identified as the second largest green space in Pasir Gudang This size is equivalent to $34.15 \%$ of size of study area. Sports area had covered 199.72 hectares or equivalent to $13.04 \%$. Green corridors that consist of buffer area and river reserve cover only 34.22 hectares of land.

The ability of people to access green spaces casily is very important to promote health and well-being. It is important that residents are able to access 
green spaces within a reasonable, or even, walkable distance from where they live or work. This is to encourage the visits of communities surrounding on foot or by bicycle, and thus, reducing emissions.

Accessibility can be expressed through, among others, distance thresholds, which represents the maximum distance that a typical user can reasonably be expected to travel. However, the attractiveness of the parks and green spaces might also be essential factor for the citizens to visit and enjoy the parks, even though the distance beyond the threshold. For green space evaluation in Pasir Gudang, the threshold represents the distribution and distance. The threshold was derived, based on the Guideline and Planning Standard for Recreation and Open Space, Department in Town and Regional planning, Peninsular Malaysia. The baseline of the threshold is that people willing to walk to their nearest accessible green spaces. This study measures the threshold for the purpose of development of green spaces strategy. The standards of distance should be set to reflect how far people prepare to travel to different typology of green spaces.

The service area was evaluated based on the typology and distribution of green spaces. The availability and accessibility of roads and pedestrian networks are the eriteria for evaluation. The analysis was executed using a function in GIS. The study found that a largest part of Pasir Gudang is served by the green spaces eatchment area (Figure 7). The total catchment area of all green spaces is $8,672.67$ hectares or $64.79 \%$ of the total area of Pasir Gudang. On the other hand, the area outside of the catchment is $3,053.21$ and $35.21 \%$. Figure 8 shows that the eastern part of study area is mostly outside green spaces service area. The eastem part is planned for new industrial development area, and thus there will be insignificant green space in this area. 


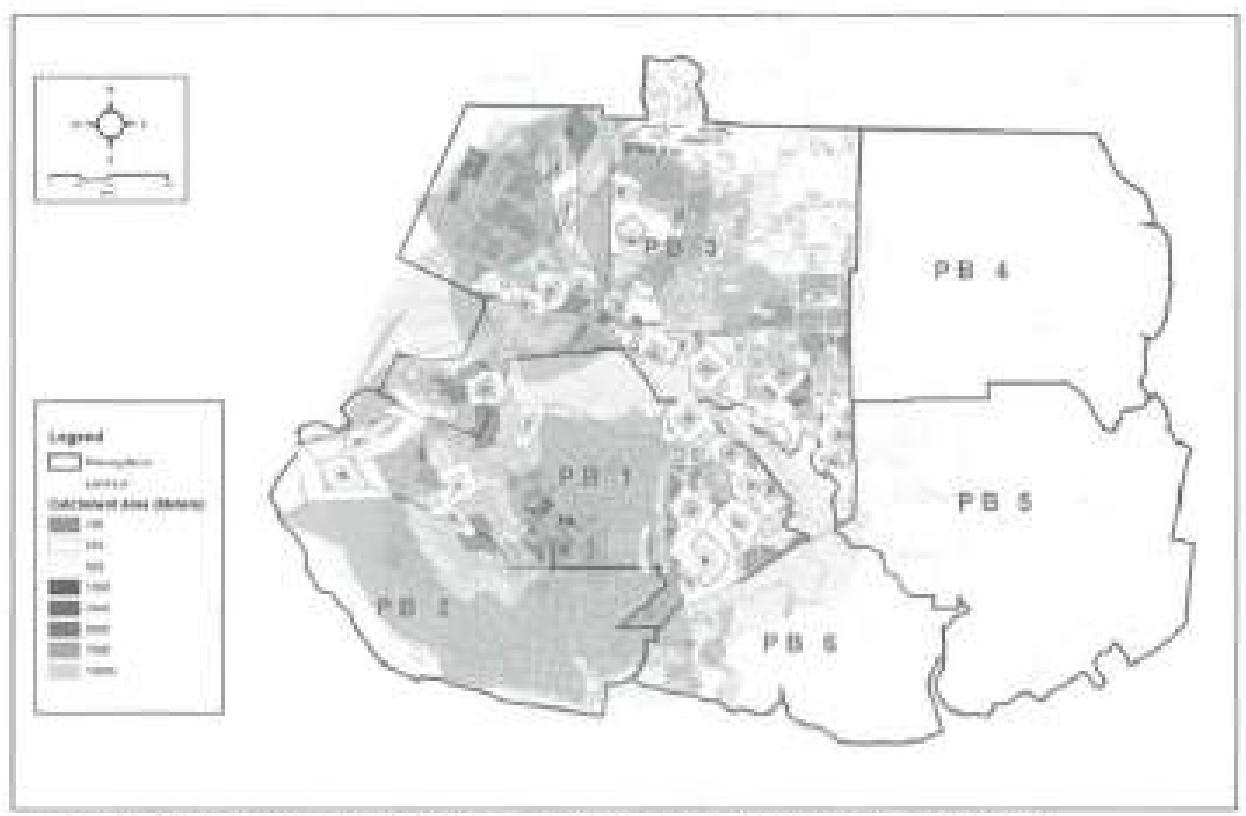

Figure 7: The Coverage Distances of All Green Spaces in Pasir Gudang

The study reveals the present catchment area of the green spaces in Pasir Gudang based on the distance and its distribution, It is obvious that almost all of the residential area in Pasir Gudang are within the catchment or service area, and therefore conveniently served by the green spaces. The service area was measured and accordingly the level of accessibility of the green spaces was identified. The town parks and community parks are the main green spaces that give a full service to the whole communities in Pasir Gudang. Nevertheless, the number and distribution of play field are quite limited for small neighbourhood.

\section{Upgrading and Enhancing Green Space Network}

Apart from the analysis of accessibility and service arca, the second part of analysis is to identify the optimum network of all the green spaces. The purpose of the analysis is to look at the potential network that can enhance the connectivity of all the green spaces in Pasir Gudang. People will be able to move conveniently from one to another green space. A network analysis has alse been done with the support of GiS function. Figure 8 shows selected roads for the purpose of enhancing green spxice network based on their distribution and distance. This network should be improved to ereate better connection of the green spaces. 


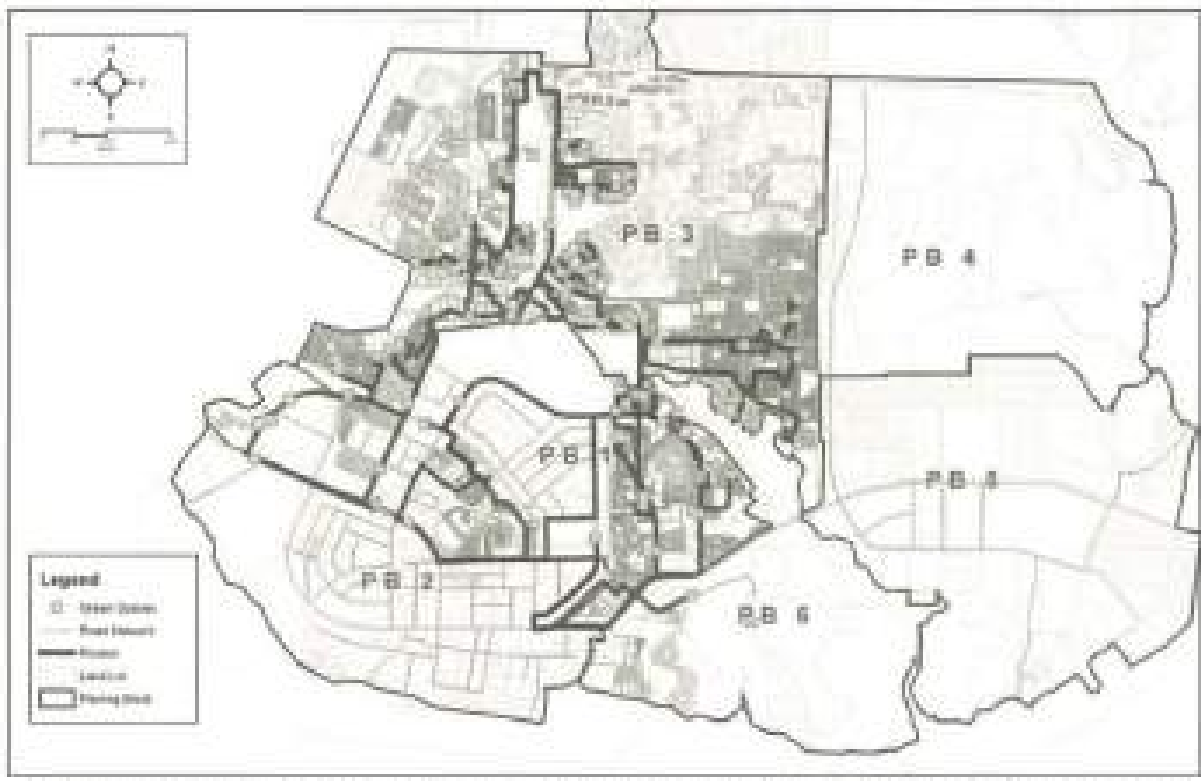

Figure 8: Selected Network for the Enhancement of the Green Space Connectivity

The network as shown in Figure 8 interconnects the green spaces and parks and may also reflect the shortest possible distance of the existing green spaces and parks from surrounding community centres i,e. residential areas. The eitizens can pass through a certain pathway in the network to arrive at any green spaces of parks safely and conveniently. The pathways along the network can be improved with respect to convenience and safety for the citizens to access the green spaces. Some connections of the green space areas and residential areas are presently inconvenient for pedestrian access since pedestrian facilities are seemingly not adequate to support safety and convenience.

Upgrading of the network i.e. connectivity is very important to create high accessibility and safe access to green space through high quality networks. In this case, a high quality network must be reflected in its safety and convenience for access by various mode of transport i.e. both pedestrians and motorized transports. A "green corridor" that connects existing green spaces is a good concept, and therefore can be applied in selected networks in the study area. The green corridor should have good vegetation and greenery sense slong the paths with high safety level for pedestrian. Some of the existing roads in the study aren have already provided pedestrian networks but still improvement of safety, pavement, shading and connection is needed. The conflict between vehicles and pedestrians also need to resolve by improving meeting points along 
the pedestrian network. For instance, zebra cnossing, pedestrian crossing bridges or tunnels, lighting and green barrier should be provided along the green corridor. This will encourage people to use the pedestrian netwotk effectively.

By considering the results of network analysis of the green space areas, this study suggests the following key strategies to improve the accessibility of green space areas by putting safety and convenience first. The key strategies include:

- Establishment of clearly defined and well-used network of accessible routes that connect communities to local green and open spaces.

- Assurance that new and enhanced green spaces are designed to have good internal access with clear entrances, good signage and clearly defined paths.

- Maximizing the opportunities for people to walk or travel to their nearest green space. A $500 \mathrm{~m}$ in distance can be adopted for local access standard in Pasir Gudang. This can be considered as the maximum distance that people should have to walk or travel to their nearest greenery area. This standard can be applied to both new and existing neighbourbood development.

- Provision of safe road crossings and teasy access point to encourage people to walk or cycle to nearby green space. Busy roads may act as barriers, thereby reducing access for nearby residents.

- Increasing accessibility of communities to presently inaccessible green spaces for recreation.

- Development of new aceessible green spaces. Where there are no suitable sites for new green space development, then the accessibility of existing green spaces should be enhanced and improved.

- Development of convenient links between green spaces and the surrounding neighbourhoods to encourage people to undertake more local journeys on foot or bicycle.

- Provision of a $500 \mathrm{~m}$ maximum walking distance standard, which is equivalent to a 10 minute walk. The proposed standard reflects the need of ensuring equity and also ensures that the pluy spaces provided are well maintained. This distance standard means that every child will be able to access an equipped playing space within $500 \mathrm{~m}$ or less of where they live.

- Provision of easily accessible playing and recreation opportunities will enable children, young people and adult to connect with the world around them, provide essential facility for bealthy and inclusive communities, and provide opportunities for safe social interaction. 


\section{CONCLUSION}

The Green Space Strategy for Pasir Gudang, as revealed by the study, is part of the audit results. It sets out the objectives for the way in which green spaces in Pasir Gudang are maintained and improved. It should be aceessible, sustainable and continue to perform a range of functions that brings benefit the whole community besides the good provision of green spaces area.

The recommendations made in this study, however, require additional resources and further investigation for implementation. This strategy can be achieved over several years through consistent approach to improve the management of existing resources and encourage greater involvement of local communities in the development as well as management of green spaces. The recommendation could be incorporated in the development plan of Pasir Gudang Local Authority.

\section{REFERENCES}

Ahris, Yaakup. (1994). Sistem Maklumat Geografi (GIS): Prinsip Asas dan Penggtenaanrya Dadam Perancangan dan Pengurusan Monograf Universiti Teknologi Malaysia: Pusat Sumber Fakulti Alam Bina.

Barbosa, O., Tratalos, J. A, et al. (2007). Who Benefits from Access to Green Space? A case study from Sheffield, UK. Landscape and Urban Planuing 83, 187-195,

Berg, A. E., Maas, J. et al. (2010). Green space as a buffer between stressful life events and health. Social Science \& Medicine, 70, 1203-1210.

Jabatan Perancangan Bandar Dan Desa, (2005). Guideline and Planning Standard for Recreation and Open Space. Kuala Lumpur: Jabatan Perancangan Bandar dan Desa Semenanjung.

Jabatan Perancangan Bandar Dan Desa, (2007). Program Bandar Selamas (Safe City Programy. Kuala Lumpur: Jabatan Perancangan Bandar dan Desa Semenanjung.

Jabatan Perancangan Bandar Dan Desa. (2009), Rancangan Tempatan Daerah Johor Bahru. Kuala Lumpur: Jabatan Perancangan Bandar dan Desa Semenanjung.

Jim, C.Y. and Chen, S.S. (2003), Comprehensive Green Space Planning based on Landscape Ecology Principles in Compact City Nanjing. China. Landscape and Urban Planing, 65, 95-116. 
Kessel, A., J. Green, R. Pinder, P. Wilkinson, C. Grundy, K. Lachowycz. (2009). Multidisciplinary Research in Public Health: A Case Study of Research on Access to Green Space". Public Health, 123, 32-38.

Kyushik, O. and Seunghyun, J. (2007). Assessing the Spatial Distribution of Urban Parks using GIS. Landscape and Urban Planuting, 82, 25-32.

Majlis Perbandaran Pasir Gudang. (2010). Statistics, Majlis Pertandaran Pasir Gudang.

Majlis Perbandaran Pasir Gudang, (2010), Local Plan Repont 2003-2020, Majlis Perbandaran Pasir Gudang.

Maruani, T. and Cohen, I. A. (2007). Open Space Planning Models: A Review of Approaches and Methods", Landscape atd Urban Planning, 81, I13.

Richands, J. A. and Xiuping Jia (1993), Remote Sensing Digiral Image Analysis; An Introduction. Berlin, Heidelberg, New York: Springer.

White, Mathew P., Ian Alcock, Benedict W. Wheeler, and Michael H. Depledge (2013). Would You Be Happier Living in a Greener Urban Area? A Fixed-Effects Analysis of Panel Data. Psychological Science Ontine First, doi: $10.1177 / 0956797612464659$.

Environmental Systems Research Institute (ESRI). Network Analyst Extension. http://www.esri.com/software/aregis/extensions/networkanalyst/index.h tml (retrieved on 10 October 2011) 